\title{
The Construction Solid Waste Minimization Practices among Malaysian Contractors
}

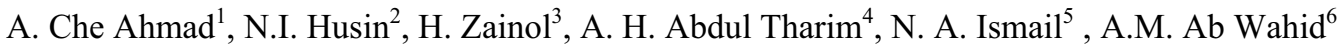 \\ 1,2,3,4,5,6 Faculty of Architecture Planning and Surveying, Universiti Teknologi MARA (Perak), Seri \\ Iskandar, 32610, Perak, Malaysia.
}

\begin{abstract}
The function of minimization of construction solid waste is to reduce or eliminates the adverse impacts on the environment and to human health. Due to the increase of population that leads to rapid development, there are possibilities of construction solid waste to be increased shortly from the construction works, demolition or renovation works. Materials such as wood, concrete, paint, brick, roofing, tiles, plastic and any other materials would contribute problem involving construction solid waste. Therefore, the proper waste minimization is needed to control the quantity of construction solid waste produced. This paper identifies the type of construction solid waste produced and discusses the waste minimization practice by the contractors at construction sites in Selangor, Kuala Lumpur and Putrajaya, Malaysia.
\end{abstract}

\section{Introduction}

The solid waste problem is one of the most debatable as well as other environmental issues such as problems of haze and air emissions from anthropogenic sources, and water problem both in terms of quantity and quality and indiscriminate dumping toxic and hazardous wastes [1]. According to GEC [2] solid waste is one of the three major environmental problems in Malaysia. Over 23,000 tonnes of waste is produced each day in Malaysia. The amount of solid waste is expected to rise to 30,000 tonnes by the year of 2020 [2]. In Malaysia, there are almost 1800 rivers, but more than half of the river have been polluted and destroyed because of the improper solid waste management [2].

The amount of solid waste collected was 70 percent lower than the amount of waste generated [1]. Amount per capita generation of solid waste varies from 0.45 to 1.44 kilograms per capita per day [1]. According to Formoso, Soibelman, Cesar and Isatto[3], the waste quantity produced are more due to insufficient in managing a waste material as compared to faulty in construction methods. The lack of waste management also can increase the waste material on site. The practice of reuse, reduce and recycle are suggested to minimize waste production by the contractors at construction sites as it could reduce the needs of new resource and cost savings in terms of transportation and disposal of waste materials to landfill [4].

Other than that, these practices could gain revenue from selling of the recycled materials [1]. The purpose of this paper is to identify the type of construction solid waste at construction sites and determine the waste minimization practiced by the contractors at Selangor, Kuala Lumpur and Putrajaya, Malaysia. 


\section{Literature Review}

\subsection{Construction solid waste}

Construction solid waste is any solid waste generated from any construction or demolition activity, including improvement, preparatory, repair or alteration works [5]. Wokekoro [6] defined that the construction and demolition waste is the waste from new construction sites, road repairs, renovation sites and razing broken pavement. According to Hsiao et al. [7], the construction waste as all wastes generated in construction works, including remaining mud, sand, stone, dirt (including the remaining volume of earthwork), brick, tile, concrete, asphalt concrete, timber, bamboo, paper, glass, pottery and porcelain, plastic, and metal, but not including general office and residential wastes (refuse, kitchen waste and excretions).

Shen et al. [8] defined the construction waste are in the form of building debris, rubble, earth, concrete, steel, timber, and mixed site clearance material that arises from various construction activities that include the land excavation or formation, civil and building construction, site clearance, demolition activities, roadwork and building renovation. Meanwhile, Tchobanoglous, Theisin and Vigil, [9] stated that waste come from construction, remodelling, repairing of individual residences, commercial buildings, and other structures are classified as a construction waste. He also stated that demolition waste is waste from razed buildings, broken-out streets, sidewalks, bridges and other structures. He also reported that the composition of construction and demolition waste is similar but latter includes broken glass, plastics, and reinforcing steel.

Construction and demolition waste are waste that's produced during construction, renovation, or demolition of structures [10]. Furthermore, the component of construction and demolition waste include concrete, asphalt, wood, metals, gypsum wallboard, roofing also for the land-clearing debris such as tree stumps, rocks, and soil. Referring to US EPA [11], construction and demolition (C\&D) debris are waste material that is produced in the process of construction, renovation, or demolition of structures. The structures include buildings of all types like residential and non-residential building as well as roads and bridges. The components of C\&D debris include concrete, asphalt, wood, metals, gypsum wallboard, and roofing. Land clearing debris, such as stumps, rocks, and dirt, are also included in some definitions of C\&D debris. Tchobanoglous et al. (1) as cited in Gavilan and Bernold [12] declared that the quantities of construction waste produced are difficult to estimate and variable in composition, which include dirt, stones, concrete, bricks, plaster, lumber, shingles, and plumbing, heating, and electrical parts.

Waste Minimization Practices

Basically, construction project has three main waste minimization practices; avoiding waste, reusing materials and recycling waste [13]. Avoiding waste refers to any practice or process that avoids, eliminates or minimizes waste at source. In addition, avoiding waste is also referred to as minimization of waste at source. Followed by reusing and recycling waste which refers to the re-using and recycling of waste materials, whereby reducing the volume of waste material to be disposed of and discharged into the environment.

According to Faniran and Caban [13] experienced practitioners in the waste and environmental pollution fields recommended that minimization of waste at source should be given the highest priority when developing strategies for waste minimization. This is because, conceptually, it makes more sense to avoid or minimize the generation of waste than to develop extensive schemes for treating waste. Besides that, re-using and recycling strategies allow waste materials to be put to beneficial use. However, reusing and recycling do not avoid the generation of waste although it approaches serve to reduce the quantity of waste to be ultimately disposed of and treated.

The significant of minimization of waste are to make sure the high quality of live, environment clean, health and safety [4]. According to Gambin et al. [14] in the New South Wales (NSW) Australia, the local and state government in NSW as well as the environmental advocates and 
community groups fulfil the goals of waste minimization and ecologically sustainable development to reduce the amount of waste into the landfill. The main aspects of an integrated approach undertaken are on demolition and construction waste. The aims is to nurture and enhance waste minimization through major consideration of reduction and recycling demolition and construction waste. Other actions taken are the development of legislation framework, promotion of best practices for waste minimization, waste reduction grant program, waste reduction and purchasing policy and setting waste targets. In order to minimize construction waste in Malaysia, National Strategic Plan for Solid Waste Management (2) put forward the Hierarchy Management of Solid Waste. The hierarchy is divided into five stages, which are reduce, reuse, recycle, treatment and disposal as Table 1.

Table 1: Hierarchy Management of Solid Waste

\begin{tabular}{ll}
\hline Hierarchy & Defination \\
\hline Reduce & Management of waste through reducing the production of solid waste \\
Reuse & Reuse the material repeatedly \\
Recycle & Production of useful material from the solid waste \\
Treatment & When the stage of reduce, reuse, and recycle is practiced, the quantity of waste can be \\
& minimized. The balance of the waste will be sent to the waste treatment centre \\
Disposal & The balance of the waste will be sent to the sanitary landfill \\
\hline
\end{tabular}

\section{Methodology}

\subsection{Sample}

This research used quantitative method with questionnaire as a survey instrument. 240 sets of questionnaire have been distributed where one set questionnaire for each construction site. The questionnaire was distributed by email, post and also face to face meeting at the construction site. 240 sets of questionnaires were distributed, and the total number returned the questionnaires is 50 (20.8\%). The remaining 184 set of questionnaire was not returned back (79.2\%). This low response to the questionnaire survey is also experienced by Berawi et al. [15]. They had experienced that out of 500 questionnaires that were distributed, returned rate was $47(9.40 \%)$. Therefore, it is acceptable for this research with the response rate of $20.8 \%$.

\subsection{Scope of research}

This research only scopes down to contractors in Klang Valley i.e; Kuala Lumpur and Selangor as well as Putrajaya due the immense location of construction and development sites. It covered all different types of construction sites including construction projects for low rise residential, high rise residential, commercial, mixed development and institution.

\subsection{Rating frequency of construction waste}

This rating frequency of construction waste is aimed to identify the types of construction waste produced to achieve the first objective of this research. The data collected according to rating frequency and level of agreement for rating construction solid waste at the construction site (Table 2).

Scale of rating frequency is defined as below [16]:

$1=$ no production of waste $\quad(0 \%)$

$2=$ less production of waste $\quad(1-30 \%)$

$3=$ severity production of waste $(31-50 \%)$

$4=$ more production of waste $\quad(51-70 \%)$

$5=$ most production of waste $\quad(71-100 \%)$ 
Table 2: Average index on level of agreement for rating construction waste

\begin{tabular}{ll}
\hline Average Index & Level of Agreement \\
\hline $0.00 \leq$ Average Index $<1.49$ & Strongly Disagree \\
$1.50 \leq$ Average Index $<2.49$ & Disagree \\
$2.50 \leq$ Average Index $<3.49$ & Neutral \\
$3.50 \leq$ Average Index $<4.49$ & Agree \\
$4.50 \leq$ Average Index $<5.00$ & Strongly Agree \\
\hline
\end{tabular}

\subsection{Average Index for Waste Minimization Practices}

The average index is aimed to identify the waste minimization practices done at the construction site to achieve the second objective of this paper. This data is presented using the average index by referring to the formula for calculation of average index from Al-Hammad and Assaf [17].

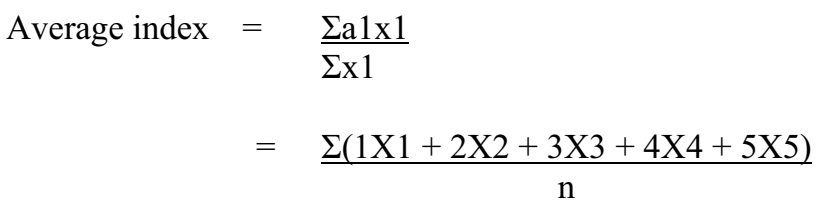

Where; $\quad \mathrm{X} 1=$ No. of respondent for not practicing

$\mathrm{X} 2=$ No. of respondent for less practice

$\mathrm{X} 3=$ No. of respondent for moderate practice

$\mathrm{X} 4=$ No. of respondent for regularly practice

$\mathrm{X} 5$ = No. of respondent for frequently practice

Below is the Table 3 for the average index on the level of agreement for waste minimization practice.

Table 3: Average index on level of agreement for waste minimization practice

\begin{tabular}{ll}
\hline Average Index & Level of Agreement \\
\hline $0.00 \leq$ Average Index $<1.49$ & Strongly Disagree \\
$1.50 \leq$ Average Index $<2.49$ & Disagree \\
$2.50 \leq$ Average Index $<3.49$ & Neutral \\
$3.50 \leq$ Average Index $<4.49$ & Agree \\
$4.50 \leq$ Average Index $<5.00$ & Strongly Agree \\
\end{tabular}

\section{Findings and Discussion}

\subsection{Respondents' Demographic}

240 sets of questionnaire survey were distributed and the total number returned the questionnaire is 50 sets $(20.8 \%)$. Thus, the total number of respondents in this research was 50 . The majority of respondents were female $(60 \%)$ while others are male $(40 \%)$. Most of the respondents were professionals i.e. quantity surveyor $(24 \%)$, engineer $(20 \%)$ and architect $(16 \%)$ while others are site supervisor (16\%), project manager (14\%) and site clerk (10\%) who involve directly at a construction site. $64 \%$ of the respondents have than 5 years working experience in the construction industry. Thus, this research is more reliable due to the experience of the majority of respondents. Berawi et al. [15] 
stated that the data obtained from the questionnaires for a respondent working experience more than 5 years are reliable due to the high level of the experience of the respondents.

\subsection{Construction site profile}

The Table 4 shows the division of the types of construction. Low rise residential is the highest percentage of $52 \%$ followed by high rise residential (22\%), mixed development (14\%), commercial $(8 \%)$ and the lowest are institutions and others type of construction which is $2 \%$. The residential project is the most favoured because 'Skim Rumah Pertamaku' or My First House has been implemented by the Malaysia government. Recently, many housing are being constructed by the government to encourage people to own a house. The government encourages contractors and developer to provide housing for low and medium income. German Chamber Network [18] reported that the housing sector is strongly going up to $37.6 \%$ with an increasing number of housing projects.

Table 4: Type of construction

\begin{tabular}{ll}
\hline Type of construction & Percentage (\%) \\
\hline Low rise residential & 52 \\
High rise residential & 22 \\
Commercial & 8 \\
Mixed development & 14 \\
Institution & 2 \\
Others & 2 \\
\hline
\end{tabular}

\subsection{Rating frequency of construction waste}

There are fifteen common types of construction waste produce during the construction works. Thus, the Table 5 shows the types of waste and the ranking of construction solid waste production. Majority of respondent agreed that the larger production of waste is timber with the mean 3.42 followed by brick, reinforcement, paint, concrete, tiles, soil, cement, hoarding, fibre, mortar, plastic, alloy/aluminium, rubber and the lowest production is glass with mean 1.94. The cut off point of 2.45 is chosen to discuss about the type of construction waste.

Table 5: Rank for mean of rating frequency for types of construction waste

\begin{tabular}{lll}
\hline Type of construction waste & Rating Mean & Rank \\
\hline Timber & 3.42 & 1 \\
Brick & 3.26 & 2 \\
Reinforcement & 2.96 & 3 \\
Paint & 2.74 & 4 \\
Concrete & 2.70 & 5 \\
Tiles & 2.66 & 6 \\
Soil & 2.48 & 7 \\
Cement & 2.46 & 8 \\
Hoarding & 2.36 & 9 \\
Fibre & 2.30 & 10 \\
Mortar & 2.26 & 11 \\
Plastic & 2.18 & 12 \\
Alloy/Aluminium & 2.04 & 13 \\
Rubber & 2.00 & 14 \\
Glass & 1.94 & 15 \\
\hline
\end{tabular}


Based on analysis mentioned, the timber is the highest production of construction waste. It is because timber is used as a temporary support especially for projects using traditional methods of construction. It used a lot of timber acts as a temporary support especially for concreting work. Nature of timber that easy to rot also becomes one of the reason why the timber is the highest rank in the production of waste. It can be proofed by Lachimpadi, Pereira, Taha, and Mokhtar [19] in their study which, timber also is the largest quantity of construction waste. Timber will be used as a temporary support to all the concreting work especially for projects using traditional method. Then, the lifespan of timber for reuse depends on the quality of the product used in construction site.

According to US EPA [11], it mentioned that timber and concrete waste are the highest component of the construction solid waste produce at the construction site of residential. The statement is seconded by Lau and Whyte [20] which also state that timber is the highest composition of waste at two from three sites in their study. Moreover, Wahid et al. [21] mentioned that the material of timber has been used at the minimum level for the construction of residential projects in Malaysia.

On second rank is brick which mean 3.26. The production of brick is high because a lot of construction is using brick especially for wall. In one building many walls are required. Llatas [22] state in his study about the production of brick as waste is the second highest of production (12\%). In study of mixed system by Lachimpandi et al. [19], they mentions the production of bricks is (4\%). While as for reinforcement, it took place at the third highest in the ranking (2.96 mean). Reinforcement become a waste when a lot of mistakes during setting works. Usually, waste of reinforcement will be sold to another person.

Furthermore, paint emerged as the fourth highest with an average of 2.74 . The production of wasted paint is more that the paint can itself. Used paint cans are categorised as packaging byproducts. This is proven by Llatas [22] in his research that stated the amount of wasted paint are more than packaging, and also the highest amount. In a research by Mcgrath [23] confirmed the finding by Llatas whereby the production of packaging byproduct is the top five ranking with $9 \%$. In addition, concrete also made their way as the top 5 ranking of waste produced with mean of 2.70 . However, in a study by Cochran et al. [24] shows the highest composition of waste for residential projects are concrete (52\%). Begum, Siwar, Pereira and Jaafar, [25], who did research on projects of construction of hostel that used conventional methods of construction in Malaysia found that the production of concrete is number five in the rank (10\%). This appears to be same with a research by Lachimpadi et al. [19] which mentions concrete and aggregate are the largest waste produced at $60 \%$.

Following the list, production of tiles ranks 6th with means at 2.66. Waste tiles are produced when the tiles are fitted according to the shape desired. Hence, leftover pieces become waste. In a study by McGrath [23], the tiles are the number four waste produced with the percentage of $22 \%$. Meanwhile, Llatas found that tiles are the biggest amount of waste produced on a construction site with $54 \%$. But as compared to study done by Lachimpadi et al. [19], tiles produces the least amount of waste at $1 \%$.

On the other hand, soil emerged with means at 2.46. Different site will produce different quantities of soil. It depends on condition of sites whether it needs to be cut or filled to get a flat ground before construction could begin. Lachimpadi et al. [19] concludes that the generation of soil waste greatly depended on the design of buildings and the landscape of the site. If the site at hilly area, it will involve a lot of cutting compared to fills, thus the surplus of soil will classified as soil waste. Begum et al. [25] found that soil and sand is the second highest for their study worth percentage (27\%). The last production of waste is glass (mean 1.94). This production of glass is supported by study of Llatas [22] found out glass is the lowest production of waste $(0.5 \%)$.

\subsection{Average Index for Waste Minimization Practices}

Table 6 shows the number, percentage and average index of respondent who gave a specific grade to each waste minimization practices. Based on the result, the highest average index is 3.62 for reuse on site and gets first

rank. Thus, the amounts of 3.62 included in the stages of age. Most of the respondents agree to reuse on site compared to leave at the site that the lowest average index 2.12 and the last rank. Many 
practices are included in the neutral category which are reused off site, recycle on site, recycle off site, sell to another person, give to another person, disposal off site, and disposal to landfill. For the practices to leave at the site, burning trash at the site, buried at the site and buried off site is included in disagree category. It is because, all the practices that include in disagree category is not good practice to be practiced at the construction site.

Table 6 shows the number, percentage and average index of respondent who gave a specific grade to each waste management practices. Based on the result, the highest average index is 3.62 for reuse on site and gets first rank. Thus, the amounts of 3.62 included in the stages of age. Most of the respondents agree to reuse on site compared to leave at the site that the lowest average index 2.12 and the last rank. Many practices are included in the neutral category which are reused off site, recycle on site, recycle off site, sell to another person, give to another person, disposal off site, and disposal to landfill. For the practices to leave at the site, burning trash at the site, buried at the site and buried off site is included in disagree category. It is because, all the practices that include in disagree category is not good practice to be practiced at the construction site.

Table 6: Average index for waste minimization practices

\begin{tabular}{|c|c|c|c|c|c|c|c|c|c|c|c|c|c|c|c|}
\hline $\begin{array}{l}\text { Management } \\
\text { Practices }\end{array}$ & $\begin{array}{l}1 \\
\text { Freq }\end{array}$ & $\%$ & $\begin{array}{c}2 \\
\text { Frec }\end{array}$ & $\%$ & $\begin{array}{l}3 \\
\text { Freq }\end{array}$ & $\%$ & $\begin{array}{l}4 \\
\text { Freq }\end{array}$ & $\%$ & $\begin{array}{l}5 \\
\text { Frec }\end{array}$ & $\%$ & $\begin{array}{l}\text { Total } \\
\text { Freq }\end{array}$ & $\%$ & $\begin{array}{l}\text { Average } \\
\text { Index }\end{array}$ & Category & Rank \\
\hline Reuse on site & 3 & 6 & 4 & 8 & 12 & 24 & 21 & 42 & 10 & 20 & 50 & 100 & 3.62 & Agree & 1 \\
\hline Recycle on site & 4 & 8 & 7 & 14 & 14 & 28 & 15 & 30 & 10 & 20 & 50 & 100 & 3.40 & Neutral & 2 \\
\hline Disposal to land fill & 3 & 6 & 9 & 18 & 13 & 26 & 18 & 36 & 7 & 14 & 50 & 100 & 3.34 & Neutral & 3 \\
\hline Sell to other person & 4 & 8 & 10 & 20 & 12 & 24 & 16 & 32 & 8 & 16 & 50 & 100 & 3.28 & Neutral & 4 \\
\hline Reuse off site & 3 & 6 & 8 & 16 & 24 & 48 & 10 & 20 & 5 & 10 & 50 & 100 & 3.12 & Neutral & 5 \\
\hline Recycle off site & 4 & 8 & 8 & 16 & 21 & 42 & 14 & 28 & 3 & 6 & 50 & 100 & 3.08 & Neutral & 6 \\
\hline Give to other person & 5 & 10 & 14 & 28 & 15 & 30 & 11 & 22 & 5 & 10 & 50 & 100 & 2.94 & Neutral & 7 \\
\hline Disposal off site & 9 & 18 & 11 & 22 & 14 & 28 & 13 & 26 & 3 & 6 & 50 & 100 & 2.80 & Neutral & 8 \\
\hline Burning on site & 15 & 30 & 15 & 30 & 12 & 24 & 6 & 12 & 2 & 4 & 50 & 100 & 2.30 & Disagree & 9 \\
\hline Buried off site & 18 & 36 & 11 & 22 & 12 & 24 & 6 & 12 & 3 & 6 & 50 & 100 & 2.30 & Disagree & 10 \\
\hline Buried at site & 20 & 40 & 12 & 24 & 10 & 20 & 6 & 12 & 2 & 4 & 50 & 100 & 2.16 & Disagree & 11 \\
\hline Leave at site & 18 & 36 & 17 & 34 & 9 & 18 & 3 & 6 & 3 & 6 & 50 & 100 & 2.12 & Disagree & 12 \\
\hline
\end{tabular}

Based on analysis mentioned the practices to reuse on site is the most practices activity do at a construction site. It is because when the reuse on site is practice it can reduce the production of waste. This analysis can be proofed by Mahayuddin [16] stated the most popular practices at construction site are reused on site. More from the total amount of production of waste will be reused at a construction site. For instance, soil and sand will be reused to fill in a dig or to do the embankment at the construction site.

However, recycle on site in the second stage which 3.40 average indexes. Have many site's practices recycled on site to minimize the production of waste. It also for maximizes the usage of the material likes timber and wood. In the case study of Mahayuddin [16] also stated that, the second practices are recycled on site.

\section{Conclusion}

There are various types of construction waste produced by different types of construction. Findings from the analysis show the highest production of construction solid waste is timber. The findings are similar with the previous research done by Lachimpadi et al. [19] which the largest production of construction solid waste is timber. The second highest type of waste is brick, followed by the third rank that is reinforcement. The forth ranking of construction waste is paint. Llatas [22] also found out that, the production of brick as construction waste is the second highest while wasted paint are produced from packaging contribute the highest amount of construction waste. Glass becomes least production of construction waste where alike the research done by Llatas [22]. 
According to Faniran and Caban [13], the waste minimization strategy should start with avoiding the generation of waste and followed by reuse of the waste. The next step is recycling the waste and last action is disposal of the waste. This is parallel with the Hierarchy Management of Solid Waste by National Strategic Plan for Solid Waste Management (2) with additional steps of treatment of waste before disposal. Findings from this research demonstrate that activities of reuse at construction site are highly being practiced by the contractors in minimizing waste. The second custom of minimizing waste practiced by the contractors are recycle of solid construction waste on site while disposal of construction waste to landfill turn out to be third rank. As wrapping up, the contractors more or less had contributed to the minimization of waste at construction site as suggested by the National Strategic Plan for Solid Waste Management. For further research, it is recommended the quantity of waste that had been minimized could be determined as proof of the practice in minimization of construction solid waste.

\section{References}

1. Hassan, M.N., Chong, T.L., Rahman, M., Salleh M.N., Zakaria, Z., \& Awang, M.(2001). Solid Waste management in Southeast Asian Countries with Special Attention to Malaysia. Proceeding Sardinia 2001 eight International Waste Management and Landfill Symposium, 1-5 October 2001. Cagliari, Italy

2. Global Environment Centre (GEC) (2012). Solid Waste in Malaysia. [Online].[Accessed 14th April 2012]. www.gecnet.info/index.cfm?\&menuid $=83$

3. Formoso, C. T., Soibelman, L., Cesare, C. D., \& Isatto, E. L. (2002). Material waste in building industry: Main causes and prevention. Journal of contruction engineering management. Vol 128, p. $316-325$.

4. Sisa.my (2012) [Online]. [Accessed 7th October 2012). Available from World Wide Web: http://www.sisa.my/cmssite/content.php?lev=2\&cat=1\&pageid=12\&lang=

5. Official national solid waste management (ONSW) (2012) [Online], [Accessed ${ }^{\text {th }}$ October 2012]. http://www.kpkt.gov.my/jpspn_en/main.php

6. Wokekoro, E. (2007) Solid waste management in the construction industry (a casestudy of Port Harcourt). International Conference "waste management, Environment Geotechnology and Global Sustainable Development, 28-30 August 2007, Ljubljana, Slovenia.

7. Hsiao, T.Y., Huang, Y.T., Yu, Y.H. \& Wernick, I.K. (2002) Modeling materials flow of waste concrete from construction and demolition wastes in Taiwan.Resource Policy. Vol 28(1-2), p. 39 $-47$.

8. Shen, L. Y., Tam, V. W. Y., Tam, C. M. \& Drew, D. (2004). Mapping Approach for Examining Waste Management on Construction Sites. Journal of construction engineering management. Vol 130, p. $472-481.108$

9. Tchobanoglous, G., Theisin, H. \& Vigil, S.A. (1993) Integrated Solid Waste Management: Engineering Principles and Management Issues. Singapore:McGRAW-HILL. P 5-21.

10. Pitchel, J. (2005) Waste Management Practices: municipal, hazardous, and industrial. United State: Taylor \& Francis Group. p. 13 - 620.

11. U.S. Environmental Protection Agency (US EPA) (1998) Characterization of Building Related Construction and demolition Debris in United Staes. Municipal and Industrial Solid waste Division, office of Solid waste. EPA530-R-98-010

12. Gavilan, R. M. \& Bernold, L. E. (1994). Source Evaluating of Solid waste in Building Construction. Journal of contruction engineering management. Vol 120, p.536 - 552.

13. Faniran, O. O., \& Caban, G. (1998) Minimizing waste on Construction project sites. Engineering, Construction and Architectural management. Vol. 5 Iss: 2, p.182 - 188. 
14. Gambin, N., Leo, C. \& Rahman, A. (2012) Recycling of construction and demolition materials as part of the waste minimization strategy in the Sydney basin and possible lessons for the Himalayas. [Online]. [Accessed 17th October 2012] http://www.aehms.org/pdf/leo\%20proceedings\%20fe.pdf

15. Berawi, M. A., Berawi, A. R. B. \& Hadwart, K. A. (2012) Managing Construction Logistics Management: Findings From Construction Contractors and Industrialised Building System(IBS) Manufacturers. African Journal of Business Management. Volume 6(5), p. 1932 - 1944.

16. Mahayuddin, S.A. (2011) Penjanaan, komposisi dan pengurusan sisa binaan:Kajian kes Ipoh, Perak. Ph.D thesis, Universiti Kebangsaan Malaysia.

17. Al-hammad, A. M. \& Assaf, S. (1996) Assessment of work performance of maintenance contractors in Saudi Arabia. Journal of management in engineering. Volume 12(1996), p. 44 - 49.

18. German Chamber Network (2012). "Market Watch 2012" Construction Industry in Malaysia. [Online].

[Accessed 20thApril2013].:http://www.malaysia.ahk.de/fileadmin/ahk_malaysia/Market_reports/The_Const ruction_Industry.pdf105

19. Lachimpadi, S. K., Pereira, J. J., Taha, M. R. \& Mokhtar, M. (2012) Construction waste minimisation comparing conventional and precast construction (mixed system and IBS) methods in high-rise buildings: a Malaysia case study. Resources, Conservation and Recycling. Vol 63 (2012), p. $96-103$.

20. Lau, H.H. \& Whyte, A. (2007). A construction waste study for residential projects in Miri, Sarawak. Proceeding Conference on Sustainable Building South-East Asia (SB07SEA) Kuala Lumpur Convention Centre. 5-7th November 2007.

21. Wahid, J., Ghani, A.N.A., Nordin, N.M. \& Idris, M.F. (2006). Teknik Binaan dan Bahan Bangunan dalam Sektor Perumahan Di Malaysia. Proceeding of International Conference on Construction Industry 2006, page 254-261.109

22. Llatas, C. (2011) A model for quantifying construction waste in projects according to the European waste list. Waste management. Vol 30 (2011), p. 1261 -1276.

23. Mcgrath, C. (2001) Waste minimisation in practice. Resources, Conservation and Recycling. Volume 32(2001), p. 227- 238.

24. Cochran, K., Townsend, T., Reinhart, D. \& Heck, H. (2007). Estimation of regional buildingrelated C\&D debris generation and composition: Case Study for Florida, US. Waste Management. Vol 27(7), p. 921 - 923.

25. Begum, R.A., Siwar, C., Pereira, J.J. \& Jaafar, A.H. (2006). A benefit-cost analysis on the economic feasibility of construction waste minimisation: The case of Malaysia. Resources, Conservation and Recycling. Vol 48(1), p. 86-98. 